\title{
Assessing the Behaviour of Pakistani Rice Producers under Exchange Rate Variability
}

\author{
Syed Rashid Ali ${ }^{*}$, Saad Uddin Khan ${ }^{1}$ and Ahmed Raza ul Mustafa ${ }^{2}$
}

${ }^{1}$ Department of Economics, University of Karachi, Pakistan; ${ }^{2}$ Department of Economics, Shaheed Benazir Bhutto University, Nawabshah, Pakistan.

\begin{abstract}
This study tries to assess the Pakistani rice producer's behaviour under the exchange rate volatility. The exchange rate variability is a risk which may force the producers to change their production preferences. The Cobb-Douglas production function used to examine the functional association between exchange rate variability and behaviour of Pakistani rice producers. The Exchange rate volatility is measured through the Moving Average Standard Deviation and time-series data from 1981 to 2018 collected from various sources. This study uses the Johansen Co-integration and Vector error correction model to assess the short run and long run association between the exchange rate variability and rice production in Pakistan. The results confirm that the appreciation in the exchange rate will adversely affect rice production in Pakistan. This negative and significant relationship confirms the risk-averse behaviour of Pakistani rice producers. Parameters stability is checked by the Cusum and Cusumq statistics. Policymakers, when designing policies to promote rice production, should consider the exchange rate volatility.

Received | July 12, 2020; Accepted | May 13, 2021; Published | November 24, 2021

*Correspondence | Syed Rashid Ali, Department of Economic, University of Karachi, Pakistan; Email: rashidali@hotmail.com

Citation | Ali, S.R., S.U. Khan and A.R. Mustafa. 2022. Assessing the behaviour of Pakistani rice producers under exchange rate variability. Sarhad Journal of Agriculture, 38(1): 103-109.

DOI | https://dx.doi.org/10.17582/journal.sja/2022/38.1.103.109

Keywords | Moving average standard deviation, Rice production, Exchange rate volatility, Risk behaviour
\end{abstract}

\section{Introduction}

$\mathrm{R}$ ice (Oryza sativa) grown nearly in six continents and is the primary food of half the world population (Chen et al., 2019). Annually, farmers grow around 700 million tons of rice globally over a cultivated area of about 158 million hectares (Childs and Nathan, 2020). Asia alone produces approximately 640 million tons of rice or $90 \%$ of global production. The United States Department of Agriculture (USDA) forecasts that in 2019/2020, world rice production will be 499.31 million metric tons, which represents a decrease of 0.06 million tons or 0.01 percent in rice production around the world (Childs and Nathan, 2020).

Rice is an essential crop of Pakistan's agriculture economy. Pakistan, the tenth-largest rice producer in the world, annually produces in the range of 7.0 to 7.5 million tons (FAO, 2021). Rice is one of the country's biggest exports earning more than $\$ 2.00$ billion a year. Pakistan is producing over 5.6 percent of the world's total rice production. In 2018-19 Pakistan produced 7500,000 metric tons of rice (FAO, 2021).

The volatility of the exchange rate plays a critical role in developing economies because developing or emerging economies are heavily dependent on foreign trade (Abbas et at., 2019). If exchange rate volatility increases, risk-averse agents will limit import/export operations. This increase in risk induce the risk-averse agents to reallocate supply to domestic markets ( $\mathrm{Yu}$, 2021). Pakistan is a developing country, and its rice 
producers have a concern about the variation in exchange rate because Pakistan exports more than $50 \%$ of its rice production globally, and the exchange rate risk can create some uncertainty in the profit of Pakistani rice producers (Khan et al., 2019). So, the main aim of this study is to evaluate the behavior of Pakistani rice producer as a risk-averse, risk-neutral or risk lover?

Exchange rate volatility is a risk that arises from unanticipated changes in the exchange rate between two currencies. International trade becomes more difficult as exchange rate volatility increases. There is an immense theoretical as well as empirical literature presenting association between exchange rate variability and foreign trade (Santana-Gallego et al., 2019; Bahmani-Oskooee and Arize, 2020; BahmaniOskooee and Saha, 2021). Since the importance of foreign trade is not understood properly, several studies found inconclusive or conflicting conclusions when analysing the nexus between exchange rate variability and foreign trade (Auboin and Ruta, 2013). Some studies found a negative impact (Molina et al., 2013; Bahmani-Oskooee and Gelan, 2018; Sauer and Bohara, 2001) while some studies found positive association (Chi and Cheng, 2016; BahmaniOskooee and Saha, 2021) and few studies found no association between exchange rate variability and foreign trade (Nishimura and Hirayama, 2013; BajoRubio et al., 2020).

Due to easily available data of developed countries, early studies used these data of exchange rate variability and foreign trade and analyse the association between these two variables. But several researchers have turned their focus to developing countries after data became available for the developing countries. Table 1 displays some studies from developed and developing countries about the exchange rate variability.

The core objective of this study is to determine how Pakistani rice producers respond when exchange rates fluctuate by taking the time series data from 1981 to 2018. This study is peculiar as it tries to assess the behaviour of rice producers under the variation in the exchange rate. It also analyses the newly available time series data from 1981 to 2018, which enables to investigate the rice production in Pakistan under the exchange rate fluctuation.

\section{Materials and Methods}

This study uses the Cobb Douglas production function to assess the behaviour of Pakistani rice producers under exchange rage variability. The Cobb Douglas production function is

$$
\begin{gathered}
\mathrm{Y}=A K^{\alpha} L^{1-\alpha} \ldots \ldots(1) \\
\mathrm{Y}=A K^{\alpha} \frac{L^{1}}{L^{\alpha}} \ldots \ldots(2) \\
\frac{\mathrm{Y}}{L}=A\left(\frac{K}{L}\right)^{\alpha} \ldots(3) \\
\mathrm{Y}=A(k)^{\alpha} \ldots \ldots(4)
\end{gathered}
$$

The generalized form of the Cobb Douglas production function presented in Equation 5, while the linearized form is in Equation 6.

$$
\begin{gathered}
\mathrm{y}=A \eta^{a_{1}} \omega^{a_{2}} \ldots(5) \\
\ln (\mathrm{y})=\ln (A)+a_{1} \ln (\eta)+a_{2} \ln (\omega) \ldots .(6)
\end{gathered}
$$

Where;

$\gamma=$ Rice Production; $\eta=$ Capital; $\omega=$ Exchange Rate; $A=$ Technology level and $\ln (A)=a_{0} ; \ln =\log$.

$$
\begin{gathered}
\ln (\mathrm{y})=a_{0}+a_{1} \ln (\eta)+a_{2} \ln (\omega) \ldots .(7) \\
\ln \left(\mathrm{\gamma}_{t}\right)=a_{0}+a_{1} \ln \left(\eta_{t}\right)+a_{2} \ln \left(\omega_{t}\right)+u_{t} \ldots \ldots(8)
\end{gathered}
$$

In Equation 8, $\gamma_{t}$ denotes the per capita rice production, $\eta_{t}$ denotes capital-labour ratio, $\omega_{t}$ denotes the variability in the exchange rate, sub-script ' $t$ ' used for the time series and ' $u_{t}$ ' denotes the error term.

\section{Exchange rate volatility measurement}

Over time, various volatility measuring techniques have developed to reflect modern econometric techniques. In the 1980s, many studies tried to use different techniques as an alternative for exchange rate volatility (Cushman, 1983). However, no clear strategy or method has yet emerged to assess the volatility. In the existing literature, various techniques for measuring variability in exchange rate are used. These includes the standard deviation approach (Chowdhury, 1993; Hayakawa and Kimura, 2009; Nishimura and Hirayama, 2013), the moving average of the standard deviation (Arize et al., 2000; Hall et al., 2010), and the Generalized Autoregressive Conditional Heteroskedasticity (GARCH) (Bahmani-Oskooee et al., 2015; Asteriou et al., 2016; Sharma and Pal, 2018). 
Table 1: Studies of developed and developing countries.

\begin{tabular}{|c|c|c|c|}
\hline $\begin{array}{l}\text { Studies of developed } \\
\text { countries }\end{array}$ & Developed countries & $\begin{array}{l}\text { Studies of developing } \\
\text { countries }\end{array}$ & Developing countries \\
\hline De Vita and Abbott (2004) & The United States & Hall et al. (2010) & $\begin{array}{l}\text { Ten EMEs and eleven other developing } \\
\text { countries }\end{array}$ \\
\hline Arize and Shwiff (1998) & G-7 countries & Sauer and Bohara (2001) & industrialized and developing countries \\
\hline Arize (1997) & $\begin{array}{l}\text { Denmark, Germany, Italy, } \\
\text { Japan, Switzerland, the } \\
\text { United Kingdom and the } \\
\text { United States }\end{array}$ & Arize et al. (2000) & 13 less developed countries (LDC's) \\
\hline Chowdhury (1993) & G-7 countries & Doroodian (1999) & India, South Korea, and Malaysia \\
\hline Asseery and Peel (1991) & $\begin{array}{l}\text { Australia, Japan, United } \\
\text { Kingdom, United States } \\
\text { and West Germany }\end{array}$ & Bahmani-Oskooee (1996) & LDCs \\
\hline Kenen and Rodrik, 1986 & $\begin{array}{l}\text { Eleven Developed } \\
\text { Countries }\end{array}$ & $\begin{array}{l}\text { Bahmani-Oskooee and } \\
\text { Ltaifa (1992) }\end{array}$ & 19 developed and 67 developing countries \\
\hline Akhtar and Hilton (1984) & Germany-United States & Medhora (1990) & $\begin{array}{l}\text { Benin, Burkina Faso, Co^te d'Ivoire, Niger, } \\
\text { Senegal, and Togo }\end{array}$ \\
\hline
\end{tabular}

Source: Author's Construction.

The use of either a nominal or a real exchange rate differs from study to study in the available literature. Many researchers tend to use the nominal exchange rate because it captures the true relative price as well as the volatility of the traded good. Akhtar and Hilton (1984) used the standard deviation method to measure the frequency of nominal exchange rate observations for each three-month duration.

Hooper and Kohlagen (1978) tried to measure the functional association between exchange rate variability with the prices and volume of traded commodities using alternate exchange rate volatility approaches. This study uses the Moving Average Standard Deviation method for exchange rate variability. This method have already used by studies (Kenen and Rodrik, 1986; Koray and Lastrapes, 1989; Lastrapes and Koray, 1990). It gives flexibility in assessing the magnitude with a span of values. The formula of equating the variation through moving average is:

$$
\left\{\frac{1}{m} \sum_{i=1}^{m}\left(E_{t}-E_{t-1}\right)^{2}\right\}^{\frac{1}{2}} \ldots \ldots
$$

Here, ' $m$ ' is the period of the value through which uncertainty is measured. In our case, we have taken it 4. Nominal exchange rate (USA dollar/ Pak Rupees) represented by $\mathrm{E}_{\mathrm{t}}$ at ' $\mathrm{t}$ ' period, $\mathrm{E}_{\mathrm{t}-1}$ is the nominal exchange rate of (USA dollar/ Pak Rupees) at $\left(\mathrm{t}^{-}{ }_{1}\right)$ period.

\section{Results and Discussion}

The annual time series data ranges from 1981 to 2018 has collected from various sources. The source of rice production (y), in Kilo Gram, is the federal bureau of statistics, Pakistan. The other variable's data, like capital $(\eta)$ and exchange rate $(\omega)$, come from the World Development Indicator and the descriptive statistics presented in Table 2.

Table 2: Descriptive statistics.

$\begin{array}{llll} & \text { } & \boldsymbol{\eta} & \boldsymbol{\omega} \\ \text { Mean } & 23.41 & 5.08 & 5.420 \\ \text { Standard Error } & 1.04 & 0.0169 & 5.509 \\ \text { Median } & 23.18 & 5.06 & 54.49 \\ \text { Standard Deviation } & 6.42 & 0.104 & 33.96 \\ \text { Sample Variance } & 41.29 & 0.0109 & 1153.58 \\ \text { Kurtosis } & -1.159 & 1.460 & -0.901 \\ \text { Skewness } & 0.342 & 0.562 & 0.485 \\ \text { Range } & 20.95 & 0.572 & 120.1 \\ \text { Minimum } & 14.46 & 4.827 & 9.9 \\ \text { Maximum } & 35.42 & 5.4 & 130 \\ \text { Sum } & 889.66 & 193.14 & 2059.83 \\ \text { No. of Observation } & 38 & 38 & 38\end{array}$

Source: Author's Construction.

This paper mainly employs the co-integration and Vector Error Correction Model that have previously been employed by others (Koray and Lastrapes, 1989; Lastrapes and Koray, 1990; Asseery and Peel, 
1991; Chou, 2000). Initially, the unit root checked for analyzing the trending behaviour of each variable. The Table 3 shows the results of the augmented Dickey and Fuller (1981) test and Philips and Perron (1988) test.

All variables are stationary at the first difference, as shown in Table 2, so the Vector Error Correction Model (VECM) employed for the long run convergent or divergent to the equilibrium. The Table 4 show the lag length criteria obtained by estimating the VAR. The optimal lag length is 1 as confirmed by all methods.

Table 5 highlights the Johansen co-integration result (Johansen, 1988). The trace statistic and Eigen Max statistic both indicate one co-integration equation confirming that variables are co-integrated.

After calculating the Johansen co-integration, then instead of a VAR in level, a vector error correction model that mixes levels and variations can be calculated and check whether VECM outperform the VAR. The results of Vector Error Correction Model presented in Equations 10 and 11, respectively.

$$
\mathrm{y}_{\mathrm{t}}=0.80186-\frac{0.032796 \eta_{\mathrm{t}}}{[0.0337]}+\frac{0.351 \omega_{\mathrm{t}}}{[12.920]} \cdots
$$

$\Delta \mathrm{y}_{\mathrm{t}}=-3.363146+3.95396 \Delta \eta_{\mathrm{t}}-0.476741 \Delta \omega_{\mathrm{t}}-0.366387 \mathrm{u}_{\mathrm{t}-1} \ldots$ (11)

In Equation 11, the magnitude and sign of the coefficient of lagged residual $(-0.366387)$ is the primary concern and it is in line with the earlier findings of Moline et al. (2013). It is an adjustment or feedback effect. It is negative and less than 0.5 confirming that the process of adjustment is very slow and converging toward equilibrium.

As all variables are stationary at the first difference, so for short-run and long-run dynamics, the vector error correction model used and the result confirm that exchange rate variability have negative and significant association with rice production in Pakistan. These findings confirm positively with the earlier finding of Akhtar and Hilton (1984), Kennen and Rodrik (1986), Cushman (1983), and opposes the findings of Asseery and Peel (1991), and McKenzie (1999). The result of VECM shows that it will take 10 years for the system to converge towards equilibrium, as presented in Table 6.

Table 3: Unit root analysis.

\begin{tabular}{lllllllll} 
Tests $\rightarrow$ & \multicolumn{2}{l}{ Augmented dickey-fuller test (ADF) } & \multicolumn{2}{l}{ Phillip-perron test (PP) } \\
Variables $\downarrow$ & Level & \multicolumn{3}{l}{ First Difference } & \multicolumn{2}{l}{ Level } & \multicolumn{2}{l}{ First Difference } \\
& C & C \& T & C & C \& T & C & C \& T & C & C \& T \\
$\gamma$ & -0.5 .2 & $-4.82^{* *}$ & $-9.34^{*}$ & $-9.418^{*}$ & -0.822 & $-4.788^{* *}$ & $-13.37^{*}$ & $-13.36^{*}$ \\
$\eta$ & -2.467 & $-3.62^{* *}$ & $-4.952^{*}$ & $-4.811^{*}$ & -1.949 & -2.73 & $-5.06^{*}$ & $-4.915^{*}$ \\
$\omega$ & -1.949 & -2.540 & $-6.531^{*}$ & $-6.459^{*}$ & -2.064 & -2.557 & $-6.523^{*}$ & $-6.482^{*}$
\end{tabular}

Note: *, **** Present significance at 1\% and 5\% and 10\% levels. Source: Author's Construction.

Table 4: Lag selection criterion (5\% significant level).

$\begin{array}{lllllll}\text { Lags } & \text { LogL } & \text { LR } & \text { FPE } & \text { AIC } & \text { SC } & \text { HQ } \\ 0 & 183.122 & \text { NA } & 6.80 \mathrm{e}-09 & -10.292 & -7.159 & -10.246 \\ 1 & 280.029^{*} & 171.662^{*} & 4.49 \mathrm{e}-11^{*} & -15.313^{*} & -14.782^{*} & -15.131^{*} \\ 2 & 285.55 & 8.838 & 5.55 \mathrm{e}-11 & -15.117 & -14.184 & -14.795 \\ 3 & 294.99 & 13.492 & 5.559 \mathrm{e}-11 & -15.142 & -13.809 & -14.682\end{array}$

*Indicates lag order selected by the criterion. Source: Author's Construction.

Table 5: Johansen co-integration test.

\begin{tabular}{llllll}
$\begin{array}{l}\text { Hypothesized } \\
\text { No. of CE(s) }\end{array}$ & Eigenvalue & Trace Statistic & $\begin{array}{l}\text { Trace } \\
\text { Probabilities }\end{array}$ & Max-Eigen Statistic & $\begin{array}{l}\text { Max-Eigen } \\
\text { Probabilities }(* *)\end{array}$ \\
\hline None* & 0.412088 & $30.54749(29.79707)$ & 0.0409 & $19.12240(21.13162)$ & 0.0933 \\
At Most 1 & 0.268605 & $11.42509(15.49471)$ & 0.1867 & $11.26083(14.26460)$ & 0.1416 \\
At Most 2 & 0.004552 & $0.164254(3.841466)$ & 0.6853 & $0.164254(3.841466)$ & 0.6853
\end{tabular}

Note: * Rejection of hypothesis at 0.05 level; ${ }^{* * *} p$-values; Critical values in parentheses. Source: Author's Construction. 
Table 6: Variance decomposition of $\gamma_{t}$.

\begin{tabular}{lllll} 
Period & S.E. & $\boldsymbol{\gamma}_{\mathbf{t}}$ & $\boldsymbol{\eta}_{\mathbf{t}}$ & $\boldsymbol{\omega}_{\mathbf{t}}$ \\
1 & 0.044756 & 100.0000 & 0.000000 & 0.000000 \\
2 & 0.048436 & 98.13124 & 0.416223 & 1.722542 \\
3 & 0.054282 & 95.67691 & 2.239666 & 2.083423 \\
4 & 0.057904 & 91.90530 & 4.529167 & 3.565529 \\
5 & 0.062207 & 87.74326 & 7.859921 & 4.396816 \\
6 & 0.066023 & 84.19717 & 10.50038 & 5.302454 \\
7 & 0.069836 & 81.35150 & 12.73753 & 5.910968 \\
\hline 8 & 0.073388 & 79.11101 & 14.44868 & 6.440312 \\
9 & 0.076808 & 77.32225 & 15.83163 & 6.846120 \\
10 & 0.080059 & 75.85104 & 16.95606 & 7.192892
\end{tabular}

Source: Author's Construction.
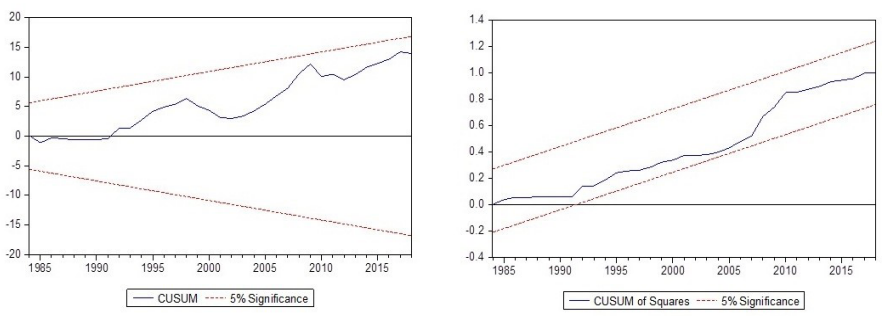

Figure 1: Results of CUSUM and CUSUMQ tests.

Source: Author's Construction

The CUSUM and CUSUMQ tests were used to verify the stability of the model, with the findings shown in Figure 1 . The results show the stability of the model with a breaking point in 1991 in the intercept term, so the pre and post model presented by using dummy variables. The values of the dummy before 1991 are Zero (0), while the value of dummy after 1991 is one (1).

The estimated results are as follows:

$$
\begin{gathered}
\mathrm{y}_{t}=0.816-0.0468 \eta_{t}+0.347 \omega_{t}+0.003 \mathrm{dum} \\
{[1.196][-0.047][7.813][0.127]}
\end{gathered}
$$

Pre 1991 model

$$
\begin{gathered}
\mathrm{y}_{t}=0.816-0.0468 \eta_{t}+0.347 \omega_{t} \\
{[1.196][-0.047][7.813]}
\end{gathered}
$$

Post-1991 model

$$
\begin{gathered}
\mathrm{y}_{t}=0.819-0.468 \eta_{t}+0.347 \omega_{t} \\
{[1.3][-0.047][7.813]}
\end{gathered}
$$

\section{Conclusions and Recommendations}

Many studies analyse the relationship between exchange rate variability and foreign trade. This study analyses the behaviour of Pakistani rice producers in the presence of exchange rate volatility by utilising the time series yearly data from 1981 to 2018. For short and long run association among the variables, this study uses Johansen co-integration and Vector Error Correction Models. The findings affirm the negative and significant effect of exchange rate fluctuations on rice production in Pakistan, confirming that a rise in exchange rate variation would negatively affect rice production and confirming Pakistani rice producers' risk-averse behaviour.

Considering the risk-averse behaviour of Pakistani rice producers, the results of this study proves that variability in exchange rate persuades the Pakistani rice producers to reduce their operations, adjust rates, or move demand-supply sources to reduce the risk of exchange-rate variability. Policymakers, when designing policies to promote rice production, should consider the variability in the exchange rate. There may be some possible limitations in this study as well. This study employed time series data with single country like Pakistan. Researchers may analyse the panel data with more than one countries.

\section{Novelty Statement}

This study is the first of its kind to assess the behavior of Pakistani rice producers under exchange rate volatility and put forward significant recommendations to the policymakers. This study confirms a short and long run negative association between exchange rate variability and rice production which further confirms the riskaverse behaviour of Pakistani rice producers under exchange rate variability.

\section{Author's Contribution}

Syed Rashid Ali: Write down the main manuscript, writeup, editing, and final revision.

Saad Uddin Khan: Drafted the outline, Data analysis and technical writing.

Ahmed Raza ul Mustafa: Summarize and supervise the manuscript.

\section{Conflict of interest}

The authors have declared no conflict of interest.

\section{References}

Abbas, S.K., A. Fazal, S.R. Ali and N. Faisal. 2019. Revaluation of fixed assets and future 
firm performance: Evidence from cement sector of Pakistan. J. Comput. Theor. Nanosci., 16(5-6): 2233-2236. https://doi.org/10.1166/ jctn.2019.7878

Akhtar, M.A. and R.S. Hilton. 1984. Effects of exchange rate uncertainty on German and U.S. Trade. Fed. Res. Bank N. Y. Quart. Rev., 9: 7-16. Arize, A.C. and S.S. Shwiff. 1998. Does exchangerate volatility affect import flows in G-7 Countries? Evidence from cointegration models, Appl. Econ., 30(10): 1269-1276. https://doi.org/10.1080/000368498324887

Arize, A.C., 1997. Conditional exchange-rate volatility and the volume of foreign trade: Evidence from seven industrialized countries. Southern Econ. J., 64: 235-254. https://doi. org/10.1002/j.2325-8012.1997.tb00017.x

Arize, A.C., T. Osang and D.J. Slottje. 2000. Exchange-rate volatility and foreign Trade: Evidence from thirteen LDC's. J. Busin. Econ. Stat., 18(1): 10-17.

Asseery, A. and D.A. Peel. 1991. The effects of exchange rate volatility on exports: Some new estimates. Econ. Lett., 37(2): 173-177. https:// doi.org/10.1016/0165-1765(91)90127-7

Asteriou, D., K. Masatci and K. P1lbeam. 2016. Exchange rate volatility and international trade: international evidence from the MINT countries. Econ. Model., 58: 133-140. https:// doi.org/10.1016/j.econmod.2016.05.006

Auboin, M. and M. Ruta. 2013. The relationship between exchange rates and international trade: A literature review. World Trade Rev., 12(3): 577-605. https://doi.org/10.1017/ S1474745613000025

Bahmani-Oskooee, M. and A. Gelan. 2018. Exchange-rate volatility and international trade performance: Evidence from 12 African countries. Econ. Anal. Policy, 58: 14-21. https:// doi.org/10.1016/j.eap.2017.12.005

Bahmani-Oskooee, M. and A.C. Arize. 2020. On the asymmetric effects of exchange rate volatility on trade flows: Evidence from Africa. Emerg. Markets Finance Trade, 56(4): 913-939. https:// doi.org/10.1080/1540496X.2018.1543582

Bahmani-Oskooee, M. and N. Ltaifa. 1992. Effects of exchange rate risk on exports: cross country analysis. World Dev., 20(8): 1173-1181. https:// doi.org/10.1016/0305-750X(92)90008-J

Bahmani-Oskooee, M. and S. Saha. 2021. On the asymmetric effects of exchange rate volatility on the trade flows of India with each of its fourteen partners. Macro. Finance Emerg. Market Econ., 14(1): 66-85. https://doi.org/1 $0.1080 / 17520843.2020 .1765826$

Bahmani-Oskooee, M., 1996. Exchange rate uncertainty and trade flows of LDCs: Evidence from johansen's cointegration analysis. J. Econ. Dev., 21(1): 23-35. http://www.jed.or.kr/fulltext/21-1/2.pdf

Bahmani-Oskooee, M., H. Harvey and S.W. Hegerty. 2015. Exchange-rate volatility and commodity trade between the USA and Indonesia. N. Z. Econ. Papers. 49(1): 78-102. https://doi.org/10.1080/00779954.2014.9011 36

Bajo-Rubio, O., B. Berke and D. McMillan. 2020. Exchange rate volatility in the Eurozone. Econ. Open-Access, Open-Assess. E-J., 14(20205): 1-23. https://doi.org/10.5018/economicsejournal.ja.2020-5

Chen,Y.,C.-YHua,J-X.Chen,B.Rathinasabapathi, Y. Cao and L.Q.Ma. 2019. Expressing arsenite antiporter PvACR3; 1 in Rice (Oryza sativa L.) decreases inorganic arsenic content in rice grains. Environ. Sci. Technol., 53(17): 10062-10069. https://doi.org/10.1021/acs. est. $9 \mathrm{~b} 02418$

Chi, J. and S.K. Cheng. 2016. Do exchange rate volatility and income affect Australia's maritime export flows to Asia? Transport Policy, 47: 13-21. https://doi.org/10.1016/j.tranpol.2015.12.003

Childs and Nathan. 2000. Rice Outlook, RCS21B, U.S. Department of Agriculture, Economic Research Service, (USDA). https://www.ers.usda.gov/publications/pubdetails/?pubid=100486

Chou, W.L., 2000. Exchange rate variability and China's exports. J. Comp. Econ., 28(1): 61-79. https://doi.org/10.1006/jcec.1999.1625

Chowdhury, A.R., 1993. Does the exchange rate volatility depress trade flows? Evidence from error correction models. Rev. Econ. Stat., 76: 700-706. https://doi.org/10.2307/2110025

Cushman, D.O., 1983. The effects of real exchange rate risk on international trade. J. Int. Econ., 15(1-2): 45-63. https://doi.org/10.1016/00221996(83)90041-7

De Vita, G. and A. Abbott, 2004. Real exchange rate volatility and US exports: An ARDL bounds testing approach. Econ. Issues, 9(1): 69-78. 
Dickey, D.A. and W.A. Fuller. 1981. Likelihood ratio statistics for autoregressive time series with a unit root. Econometrica, 49(4): 10571072. https://doi.org/10.2307/1912517

Doroodian, K., 1999. Does exchange rate volatility deterinternational trade in developing countries? J. Asian Econ., 10(3): 465-474. https://doi. org/10.1016/S1049-0078(99)00038-X

FAO, 2021. Food and Agriculture Organization of the United Nations. FAOSTAT statistical database. http://www.fao.org/faostat/en/

Hall, S., G. Hondroyiannis, P. Swamy, G. Tavlas and M. Ulan. 2010. Exchange-rate volatility and export performance: Do emerging market economies resemble industrial countries or other developing countries? Econ. Model., 27(6): 1514-1521.

Hayakawa, K., and F. Kimura. 2009. The effect of exchange rate volatility on international trade in East Asia. J. Japanese Int. Econ., 23(4): 395406. https://doi.org/10.1016/j.jjie.2009.07.001

Hooper, P. and S.W. Kohlhagen. 1978. The effect of exchange rate uncertainty on the prices and volume of international trade. J. Int. Econ., 8(4): 483-511. https://doi.org/10.1016/00221996(87)90001-8

Johansen, S., 1988. Statistical analysis of cointegration vectors. J. Econ. Dyn. Contr., 12: 231-254. https://doi.org/10.1016/01651889(88)90041-3

Kenen, B. Peter and R. Dani. 1986. Measuring and analyzing the effects of short-term volatility in real exchange rates. Rev. Econ. Stat. MIT Press, 68(2): 311-315. https://doi. org/10.2307/1925511

Khan, S.D., S.R. Ali and S.W. Khattak. 2019. Exchange rate volatility and cotton producer's behaviour: Evidence from Pakistan. Sarhad J. Agric., 35(4): 1259-1265. https://doi. org/10.17582/journal.sja/2019/35.4.1259.1265

Koray, F., and W. Lastrapes. 1989. Real exchange rate volatility and U.S. bilateral trade: A VAR approach. Rev. Econ. Stat., 71(4): 708-712. https://doi.org/10.2307/1928117

McKenzie, M.D., 1999. The impact of exchange rate volatility on international trade flows. $J$. Econ. Surv., 13(1): 71-106. https://doi. org/10.1111/1467-6419.00075

Lastrapes, W. D. and F. Koray, 1990. Exchange rate volatility and U.S. multilateral trade flows. J. Macroecon., 12(2): 341-362. https://doi.
org/10.1016/0164-0704(90)90001-Q

Medhora, R., 1990. The effect of exchange rate variability on trade: The case of the West African Monetary Union's imports. World Dev., 18(2): 313-324. https://doi.org/10.1016/0305750X(90)90055-3

Molina, I.R., S. Mohanty, V. Pede and H. Valera. 2013. Modelling the effects of exchange rate volatility on Thai rice exports. Selected paper, annual meeting, Agricultural and Applied Economics Association, Washington DC. https://ageconsearch.umn.edu/ record $/ 150429 ? \mathrm{ln}=\mathrm{en}$

Nishimura, Y. and K. Hirayama. 2013. Does exchange rate volatility deter Japan-China trade? Evidence from pre- and post-exchange rate reform in China. Japan World Econ., 25-26: 90-101. https://doi.org/10.1016/j. japwor.2013.03.002

Phillips, P.C. and P. Perron. 1988. Testing for a unit root in time series regression. Biometrika, 75(2): 335-346. https://doi.org/10.1093/ biomet/75.2.335

Santana-Gallego, M. and J.V. Pérez-Rodríguez. 2019. International trade, exchange rate regimes, and financial crises. N. Am. J. Econ. Finance, 47: 85-95. https://doi.org/10.1016/j. najef.2018.11.009

Sauer, C. and A.K. Bohara. 2001. Exchange rate volatility and exports: Regional differences between developing and industrialized countries. Rev. Int. Econ., 9: 133-152. https:// doi.org/10.1111/1467-9396.00269

Sharma, C. and D. Pal. 2018. Exchange rate volatility and India's cross-border trade: A pooled mean group and nonlinear cointegration approach. Econ. Model., 74: 230-246. https:// doi.org/10.1016/j.econmod.2018.05.016

Yu, M., 2021. Exchange rate movements and exporter profitability. In: Exchange Rate, Credit Constraints and China's International Trade. Palgrave Macmillan, Singapore. https:// doi.org/10.1007/978-981-15-7522-8 